\title{
Histone H3.1t
}

National Cancer Institute

\section{Source}

National Cancer Institute. Histone H3.1t. NCI Thesaurus. Code C154671.

Histone H3.1t (136 aa, 16 kDa) is encoded by the human H3-4 gene. This protein is involved in formation of higher order chromatin structures. 